\title{
Alteration of Some Heavy Metals and Kidney Function Tests in Serum of Crude Oil Station Workers
}

\author{
Vyan A. Qader ${ }^{1 *}$, Sardar N. Ahmed ${ }^{2}$ Ayad F. Palani ${ }^{3}$
}

${ }^{1}$ Department of Chemistry, Faculty of science and health, Koya University, Daniel Mitterrand Boulevard, Koya KOY45 AB64, Kurdistan Region, Iraq

${ }^{2}$ Department of clinical Biochemistry, Hawler Medical University, Erbil, Kurdistan Region, Iraq

${ }^{3}$ Department of Chemistry, College of science, University, Garmian, Kalar, Kurdistan Region, Iraq *Corresponding Author. Email: vyan.asad@koyauniversity.org

\section{Abstract}

Some trace metals have no biological role, are toxic when in a certain form and concentration. The aim of the present study is to study the effects of exposure to the vapors of crude oil (vehicle fuel) on some trace elements value and kidney function tests in serum of crude oil station workers. The study includes (30) men crude oil station workers (group 1), and (30) men non crude oil station workers (group 2). The mean value of serum aluminum $(\mathrm{Al})$, barium $(\mathrm{Ba})$, zinc $(\mathrm{Zn})$, manganese $(\mathrm{Mn})$, iron $(\mathrm{Fe})$, and vanadium (V) were significantly higher in (group 1) compared with (group 2) $(\mathrm{p}<0.05)$, while the mean value of serum silver $(\mathrm{Ag})$ in group 2 was significantly higher than that of group 1 , while $\{$ mercury $(\mathrm{Hg})$, and lead $(\mathrm{Pb})$ \} in group 1 no significantly higher than that of group2, the serum creatinine and uric acid in group 1 was significantly higher than that of group 2, and serum urea in group 1 was non significantly higher than that of group 2. Based on the findings of the present study, it can be concluded trace elements in serum of crude oil station workers are abnormal and affect dramatically of kidney functions.

Keywords: crude oil station worker, trace elements, urea, creatinine, uric acid

\section{Introduction}

Crude oil (petrol) is a complex manufactured mixture that does not exist naturally in the environment. It consists mostly of several hundred hydrocarbons obtained by the fractional distillation of petroleum that have boiling points from approximately $40^{\circ} \mathrm{C}$ to $180^{\circ} \mathrm{C}$. The hydrocarbons present in the gasoline mixture include alkanes, or straight chain C5 to C12 compounds or branched-chain compounds of the same size; alkenes, which are unsaturated linear and branched-chain hydrocarbon, also saturated cyclic hydrocarbons. Also included in the gasoline is aromatic compounds (principally benzene, toluene, ethyl-benzene, and xylenes) [1]. 
Exposure to crude oil occurs by: Breathing, drinking contaminated water and Being close to where gasoline has spilled or leaked into the soil. Certain workers have a greater risk of exposure to gasoline vapors. These include service station attendants, drivers of gasoline, and refinery workers [2].

Heavy metals are described as those metals which, in their standard state, have a specific gravity of more than $5 \mathrm{gm} / \mathrm{cm}^{3}$, and atomic weight of $63.5-200.6$ [3]. The heavy metals are responsible for many pernicious effects on human health such as saturnism (lead contamination), immunodepression and skin diseases (zinc and copper contamination), cancer (cadmium), hyperkeratosis (arsenic), neurological disorders (manganese) or blood disorders (iron) [4].

When not digest heavy metals accumulate in the human bodybecomes toxic and cause many problems for human health,including damage to the nerves and the central, bloodcomposition and many organs especially kidneys and these metals become toxicwhen an increase from the normal level allowed. As a rule,acute poisoning is more likely to result from inhalation or skincontact of dust, fumes or vapors, or materials in the workplace $[5,6]$.

Certain trace elements (TEs) are essential for life and health of the human, they are essential for the metabolism, growth and survival, there are an alteration in the levels TEs caused by air, water, and food contamination by environmental pollution [7].

A lot of TEs have an important influence on risk factors like disorders of blood pressure, blood lipids, glucose intolerance, coagulation and circulating insulin [8], high exposure cause defect of organs especially liver and kidneys.

The kidney is the first target organ of heavy metal toxicity. The extent of renal damage by heavy metals depends on the nature, the dose, route and duration of exposure. Both acute and chronic intoxication have been demonstrated to cause nephropathies [9].

The aim of the work is to obtain the effects of pollution by exposure (crude oil station workers) on serum heavy metals ( $\mathrm{Hg}, \mathrm{Pb}, \mathrm{Cd}, \mathrm{Ag}$ and $\mathrm{V}$ ), trace elements ( $\mathrm{Al}, \mathrm{B}, \mathrm{Fe}, \mathrm{Mn}$, and $\mathrm{Zn}$ ) on kidney function tests (urea, creatinine and uric acid).

\section{Materials and Methods}

\section{A. Subjects}

This study was conducted over a period of one year, from January to December 2017, and the subjects included (30) men crude oil station workers (group 1), ages (43.46 \pm 9.55$)$, and (30) men non crude oil station workers (control) (group 2), mean ages $(45.15 \pm 6.5)$. 


\section{B. Sampling}

Four to six milliliters venous blood was withdrawn from each individual using disposable syringe. The samples after half hour centrifuged for [10] $\mathrm{min}$ at $3000 \mathrm{rpm}$, and the serum obtained was analyzed directly.

C. Estimation of serum heavy metals and trace elements

The sample was prepared by addingone milliliter of serum into disposable plastic (polystyrene) tube, then added 9 milliliters of 5\% nitric acid (Already prepared from Nitric Acid, 67-70\%, Fisher Scientific- CAS: 7697-37-2), mixed and incubate for 6 -10 hours at room temperature, centrifuged at $4000 \mathrm{~g}$ for 10 minutes, separated clear supernatant solutions, used for determination of serum trace and heavy metals by using inductively coupled plasma optical emission spectrophotometer (ICP-OES, Optima 2100 DV, Perkin Elmer-USA).

\section{Preparation of Standard curve}

The calibration curve of trace metals were obtained from five different known standard solutions, as $(1 \mathrm{mg} / \mathrm{L}, 2 \mathrm{mg} / \mathrm{L}, 3 \mathrm{mg} / \mathrm{L}, 4 \mathrm{mg} / \mathrm{L}$, and $5 \mathrm{mg} / \mathrm{L})$ were prepared from a $100 \mathrm{mg} / \mathrm{L}$ standard (or stock) solutionand heavy metalswere obtained from five different known standard solutions, as $(1 \mathrm{ug} / \mathrm{L}, 10 \mathrm{ug} / \mathrm{L}, 30 \mathrm{ug} / \mathrm{L}, 50 \mathrm{ug} / \mathrm{L}$, and $100 \mathrm{ug} / \mathrm{L}$ )were prepared from a $100 \mathrm{ug} / \mathrm{L}$ standard (or stock) solution(ICP multi-element standard solution VIII, 1.09492 - Merck, Germany). 5\% $\mathrm{HNO}_{3}$ was used for dilution [10, 11]. The following table is limit of detection (LOD) (ug/L), limit of quantization(LOQ) (ug/L), and wave length for each element

\begin{tabular}{|l|l|l|l|}
\hline Elements & $\begin{array}{l}\text { Limit of detection } \\
\text { (LOD) (ug/L) }\end{array}$ & $\begin{array}{l}\text { Limit of quantization } \\
\text { (LOQ) (ug/L) }\end{array}$ & Wave length (nm) \\
\hline $\mathrm{Ag}$ & 0.5 & 1.6 & 328.07 \\
$\mathrm{Al}$ & 162.2 & 540.6 & 308.213 \\
$\mathrm{Ba}$ & 0.3 & 1.0 & 233.523 \\
$\mathrm{Cd}$ & 3.9 & 13.2 & 317.935 \\
$\mathrm{Fe}$ & 2.7 & 9.0 & 259.943 \\
$\mathrm{Hg}$ & 3.7 & 22.4 & 198.023 \\
$\mathrm{Mn}$ & 0.5 & 1.2 & 220.352 \\
$\mathrm{~Pb}$ & 3.4 & 11.3 & 196.026 \\
$\mathrm{~V}$ & 0.2 & 0.5 & 292.402 \\
$\mathrm{Zn}$ & 1.1 & 1.7 & 213.858 \\
\hline
\end{tabular}

d. Evaluation of kidney function test

The serum urea, creatinine and uric acid were estimated (enzymatic method) by using the Biolabo diagnostic kit with fully automated biochemical analyzer. 
e. Statistical analysis

SPSS version 22 for windows was used in the analysis of the data obtained. Statistical analysis was assessed using student t-test. Mean \pm SD value was adopted in the determinations. P-values less than 0.05 were considered statistically significant.

\section{Results}

Mean \pm SD of estimated heavy metals are shown in table (I). The results obtained indicated that the mean serum $\mathrm{Pb}$ and $\mathrm{Hg}$ in group 1 were non significantly higher than that of group2 $(\mathrm{P}>0.05)$, the heavy metal $\mathrm{Cd}$ not present in serum of both groups, the serum $\mathrm{V}$ in group 1 significantly higher than that of group $2(\mathrm{P}<0.05)$, while serum $\mathrm{Ag}$ in group 2 was significantly higher than that of group $1(\mathrm{P}<0.001)$.

TABLE I

HEAVY METALS IN CRUDE OIL STATION WORKERS AND CONTROL

\begin{tabular}{llll}
\hline \hline Parameters & Control group & Exposure group & $\mathrm{P}$ value \\
\hline $\mathrm{Pb}(\mathrm{ug} / \mathrm{L})$ & $11.4 \pm 6.2$ & $13.3 \pm 4.7$ & $\mathrm{P}>0.05$ \\
$\mathrm{Hg}(\mathrm{ug} / \mathrm{L})$ & $35 \pm 0.24$ & $36 \pm 0.15$ & $\mathrm{P}>0.05$ \\
$\mathrm{~V}(\mathrm{ug} / \mathrm{L})$ & $1.4 \pm 0.57$ & $2.8 \pm 0.93$ & $\mathrm{P}<0.05$ \\
$\mathrm{Cd}(\mathrm{ug} / \mathrm{L})$ & 0.0 & 0.0 & 0.0 \\
$\mathrm{Ag}(\mathrm{ug} / \mathrm{L})$ & $0.8 \pm 0.07$ & $0.65 \pm 006$ & $\mathrm{P}<0.001$ \\
\hline \hline
\end{tabular}

Results expressed as Mean $\pm \mathrm{SD}$

$P$ value: probability value

Some serum trace element levels in crude oil station workers and control groups.

Results in the table (II) showed the mean \pm SD of trace elements (Ba, Al, Fe, Zn, Zn and $\mathrm{Mn})$ in sera of crude

oil station workers and control groups. Significant elevation were found in all the trace elements in crude oil station

workers compared with that in normal group with different probably values ( $\mathrm{Ba}$ and $\mathrm{Al}$ $\mathrm{p}<0.05$ ), but (Fe and $\mathrm{Zn}$

$\mathrm{P}<0.01$, while the trace element in crude oil station workers was highly significantly $(\mathrm{P}<0.001)$ higher than that

of control group. 
TABLE II

TRACE ELEMENTS IN CRUDE OIL STATION WORKERS AND CONTROL

\begin{tabular}{llll}
\hline \hline Parameters & Control group & Exposure group & $\mathrm{P}$ value \\
\hline $\mathrm{Ba}(\mathrm{mg} / \mathrm{L})$ & $0.47 \pm 0.1$ & $0.58 \pm 0.18$ & $\mathrm{P}<0.05$ \\
$\mathrm{Al}(\mathrm{mg} / \mathrm{L})$ & $0.98 \pm 0.21$ & $1.39 \pm 0.46$ & $\mathrm{P}<0.05$ \\
$\mathrm{Fe}(\mathrm{mg} / \mathrm{L})$ & $0.21 \pm 0.043$ & $0.36 \pm 0.1$ & $\mathrm{P}<0.01$ \\
$\mathrm{Zn}(\mathrm{mg} / \mathrm{L})$ & $0.072 \pm 0.05$ & $0.175 \pm 0.06$ & $\mathrm{P}<0.01$ \\
$\mathrm{Mn}(\mathrm{mg} / \mathrm{L})$ & $0.006 \pm 0.004$ & $0.19 \pm 0.1$ & $\mathrm{P}<0.001$ \\
\hline \hline
\end{tabular}

Results expressed as Mean \pm SD

Concentration of serum urea, creatinine and uric acid in crude oil station workers and control: -

Table (III) provided the mean S.urea, creatinine and uric acid in crude oil station workers and control groups. The results obtained indicated that the mean S.urea in group 1 was not significantly higher than that of group 2, the mean S.creatinine in group 1 was significantly higher than that of group $2,(\mathrm{P}<0.05)$, and the mean S.uric acid in group 1 was significantly higher than that of group $2,(\mathrm{P}<0.01)$.

TABLE III

UREA, CREATININE AND URIC ACID IN CRUDE OIL STATION WORKERS AND CONTROL

\begin{tabular}{lcll}
\hline \hline Parameters & Control group & Exposure group & $\mathrm{P}$ value \\
\hline $\begin{array}{l}\text { Serum urea }(\mathrm{mg} / \mathrm{dl}) \\
\begin{array}{l}\text { Serum creatinine } \\
(\mathrm{mg} / \mathrm{dl})\end{array}\end{array}$ & $27.35 \pm 9.37$ & $30.5 \pm 7.33$ & $\mathrm{P}>0.05$ \\
$\begin{array}{l}\text { Serum uric acid } \\
(\mathrm{mg} / \mathrm{dl})\end{array}$ & $4.6 \pm 1.4$ & $6.34 \pm 1.25$ & $\mathrm{P}<0.05$ \\
\hline \hline
\end{tabular}

Results expressed as Mean \pm SD

\section{Discussion}

The toxicity effect of certain metals in some forms and doses on health, certain metals have no biological role, it means are not essential minerals, or are toxic when in a certain form [12], for example the heavy element lead in any amount will affect human health [13], which cause anemia and affect organs especially kidneys [4]. The heavy metals such as lead, mercury and cadmium, all have electron-sharing affinities that can result information of covalent attachments [14]. These attachments are mainly formed between 
heavy metals and sulfhydryl groups of proteins [15]. In the present the metals the heavy metals $\mathrm{Pb}$ and $\mathrm{V}$ in exposure group (group 1) was not significantly higher than that of control group (group 2), the same results obtained by Adnan et al [16].

In current study all the trace elements $\mathrm{Ba}, \mathrm{Al}, \mathrm{Fe}, \mathrm{Zn}$ and $\mathrm{Mn}$ in serum of exposure group were significantly higher than that of control group. Trace elements as $\mathrm{Zn}, \mathrm{Fe}$ and $\mathrm{Mn}$ participate in the regulation of multiple biochemical metabolisms and physiological functions (e.g. nucleic acid and protein synthesis, enzymatic reactions, membrane stabilization, immune system function, antioxidant defenses, oxidative phosphorylation, etc.). These metals are effective at very low concentrations, and their concentration in body fluids must be tightly regulated: deficiency or excess both cause severe illness and death. Thus, urinary excretion by the kidney, together with the gastrointestinal absorption rate, plays an important role in regulating the plasma level of these elements. Although the renal handling of cations is not fully understood, it is probable that each segment of the nephron is involved in their reabsorption; even so $70 \%$ of the transport occurs along the proximal tubule $[17,18]$.

In current study analyzed kidney function tests (urea, creatinine and uric acid), obtained that serum urea and creatinine of exposure group were significantly higher than that of control group $(\mathrm{P}<0.05)$, and uric acid in serum of exposure group were significantly higher than that of control group $(\mathrm{P}<0.01)$, caused by the body is contaminated by heavy metals $\mathrm{Hg}, \mathrm{Pb}$ and $\mathrm{V}$, and also high level of trace elements $\mathrm{Mn}$. $\mathrm{Zn}$ and Fe. Therefore, the kidney will be confronted with two problems;

1- The entry of the toxic metal into the renal cells

2- The concomitance of the essential trace elements entry due to competition with the toxin [19].

Renal failure occurs were the kidneys cannot ability to remove the body metabolic waste products (urea, creatinine and uric acid), leading to accumulate in the body fluids as a result of impaired renal excretion and lead to a disruption in endocrine and metabolic functions as well as fluid, electrolyte, and acid-based disturbances, all this participative in renal failure [20].

\section{Conclusion}

This study concluded that human exposure to crude oil cause increase heavy metals in blood circulation especially vanadium and lead, also increase serum essential elements $(\mathrm{Mn}, \mathrm{Zn}$ and $\mathrm{Fe}$ ), and each of ( $\mathrm{Ba}$ and $\mathrm{Al}$ ) non-essential trace elements was increased, and kidney function tests are elevated especially creatinine and uric acid.

\section{Reference}


[1] MA. Mehlman. Dangerous properties of petroleum-refining products: carcinogenicity of motor fuels (gasoline). TeratogenesisCarcinog Mutagen. 1990, (10) pp: 399-408.

[2] H. Carolyn and JL. John. Toxicological profile for gasoline.U.S. Department of Health and Human Services. Public health service agency for toxic substances and disease registry. 1995.

[3] Aslam B, Javed I, Khan H F and Zia-ur-Rahman. Uptake of heavy metal residues from sewage sludge in the goat and cattle during summer season. Pakistan Veterinary Journal.2011, 31(1), 75-77.

[4] allanGow, Michael J. Murphy, Rajeef Srivastava, Robert A. Cowan and Denis St. j. OReilly. Clinical biochemistry, an illustrated color text.fifth edition. Churchill livingstone. Elsevier. Toronto 2013.

[5] Mortada W.I., Sobh M.A., El-Defrawy M.M., FarahatS.E., Study of lead exposure from automobile

exhaust as arisk for nephrotoxicity among traffic policemen, Am JNephro. 2001,21(4), 274-9

[6] Hong Y.C., Park E.Y., Park M.S., Ko J.A., Oh S.Y. andKim H., et al. Communitylevel exposure to chemicalsandoxidative stress in adult population. Toxicol Lett. 2009, 184,139-44

[7] Henry A. Schroeder. The role of trace elements in cardiovascular diseases.Medical clinics of North America. 1974, 58(2):381.

[8] Elif Ari, Yuksel Kaya, HalkitDemir, EbruAsicicoglue, SiddikKeskin. The correlation of serum trace elements and heavy metals with carotid artery atherosclerosis in maintenance hemodialysis patients.Biological Trace Element Research. 2011, 144(13):351-9.

[9] Liu J, Habeebu SS, Liu Y, Klaassen CD: Acute CdMT injection is not a good model to study chronic $\mathrm{Cd}$ nephropathy: Comparison of chronic $\mathrm{CdCl} 2$ and $\mathrm{CdMT}$ exposure with acute CdMT injection in rats. ToxicolApplPharmacol 1998, 153:4858.

[10] Massadeh, A., et al., Simultaneous determination of $\mathrm{Cd}, \mathrm{Pb}, \mathrm{Cu}, \mathrm{Zn}$, and $\mathrm{Se}$ in human blood of

Jordanian smokers by ICP-OES. Biological trace element research, 2010, 133(1): p. 1.

[11] Bakircioglu, D., Y.B. Kurtulus, and G. Ucar, Determination of some traces metal levels in cheese samples packaged in plastic and tin containers by ICP-OES after dry, wet and microwave digestion. Food and Chemical Toxicology, 2011, 49(1): p. 202-207 
[12] Dartmouth Toxic Metals Superfund Research Program. 2012-05-30. Archived from the original on 2013-12-30. Retrieved 2013-12-29.

[13] Jump up $\wedge "$ Announcement: Response to the Advisory Committee on Childhood Lead Poisoning Prevention Report, Low Level Lead Exposure Harms Children: A Renewed Call for Primary Prevention". Centers for Disease Control and Prevention. 2012-05-25. Archived from the original on 2017-04-30.

[14] Bondy, S.C., Oxygen generation as a basis for neurotoxicity of metals. In: Toxicology of metals, Chang, L.W.; Eds,;RCPress, Baco Raton. 1996, pp 699-706 [15] Quig D. Cysteine, metabolism and metal toxicity, Alter.Med.Rev.1998,3, 262-70.

[16] Adnan J. M, AL-Fartosy, Nadhum A, Awad and Sanna K. Shanan. Biochemical correlation between some heavy metals, malondialdehyde and total antioxidant capacity in blood of gasoline station workers.Int. res. J. Environment. Sci. 2014, vol. 3(9); pp 56-60.

[17] Ducoudret O, Barbier O, Tauc M, Fuchs M, Poujeol P: Characterization of Zn2+ transport in Madin-Darby canine kidney cells. BiochimBiophysActa 2003, 1611.pp171-179.

[18] Felley-Bosco E, Diezi J: Fate of cadmium in rat renal tubules: A microinjection study. ToxicolApplPharmacol 1987, 91, pp 204-211.

[19] Gachot B, Tauc M, Morat L, Poujeol P: Zinc uptake by proximal cells isolated from rabbit kidney: Effects of cysteine and histidine. Pflügers Arch 1991, 419.pp 583-7.

[20] Al-Jawadi A. M. Zena. Clinical and biochemical study of acute renal failure disease. Nati.J. of Chemistry. 2006, 21, pp 119-124. 